\title{
A 450 Year Old Turkish Poem, Art as a Qualitative Investigation Tool, Buddhist Deathways, Karma and Eudaimonia in Death and Organ Donation: The Wonders of Truly Diverse Bioethical Inquiry!
}

\author{
Michael A. Ashby \\ Received: 3 July 2017 / Accepted: 4 July 2017 /Published online: 16 August 2017 \\ (C) Journal of Bioethical Inquiry Pty Ltd. 2017
}

Keywords Poetry · Art based research $\cdot$ Buddhism $\cdot$ End of life $\cdot$ Eudaimonia $\cdot$ Organ Donation

This is one of our non-themed issues in that there is no symposium or special subject to dominate the menu. The papers that follow are then a typical fractal of the work submitted to us, of the issues and tensions that authors wish to put into the global bioethics conversation. As nearly always, there is a fair amount about the beginnings and endings of life and the choices that may or may not be available as a result of technological capability. The manifestations of autonomy also loom large, freedoms understood and not, the determination of best interests, by whom and for whom. In a number of contributions the bioethical meets the spiritual and existential in its many forms. True to the multifaceted ethos of the journal, diverse modalities and arts are mixed with the logical-positive and hard logic, from brain death, via sex selection, the visual arts to examine immunization refusal, to a consideration of death and grief in Pure Land Buddhism.

\section{A. Ashby $(\bowtie)$}

Palliative Care Service, Royal Hobart Hospital, Tasmanian Health Service, and School of Medicine, Faculty of Health Sciences, University of Tasmania, 1st Floor, Peacock Building, Repatriation Centre, 90 Davey Street, Hobart, TAS 7000, Australia e-mail: michael.ashby@ths.tas.gov.au
In the regular legal Recent Developments column, Richards explores two issues (Richards and Pope 2017). The first, in the case of Re Carla (Medical procedure) [2016] FamCA 7, shows how legal holdings can be acceptable to all parties but pose problems in terms of legal precedent and principles thereby established. It is important for us all to understand that the intrinsic workings of the law require analysis in their own right, even when the outcome judgment seems fair and reasonable in the circumstances. The second section, written by a U.S. colleague, T.M. Pope from Minnesota, reviews the recent considerations of brain death in a case and legislation in the state of Nevada, an issue largely governed hitherto in American jurisdictions by adoption of the Uniform Determination of Death Act (UDDA). A central issue is the administration of an apnoea test to determine whole of brain, including brain stem, death, and consent for this test to be administered.

In Futile Treatment-A Review, Lenko Šarić, Ivana Prkić, and Marko Jukić, from Croatia question the nature of futility in the intensive care context, where physiological system maintenance may eclipse quality of life and holism (Šarić et al. 2017).

In Are Wrongful Life Actions Threatening the Value of Human Life? Vera Lúcia Raposo from Portugal and Macau provide an analysis of the rights of the unborn child to either not be born or to be compensated for medical decisions that lead to a life of severe disability compared to healthy persons (Raposo 2017). The value of life itself is weighed up against life with great limitations and 
suffering, with the conclusion that sometimes, especially at the law, life resultant from medical intervention is so burdensome that compensation is required.

In Political Minimalism and Social Debates: The Case of Human-Enhancement Technologies, Javier Rodríguez Alcázar, from Spain states that

I will argue that political moralism is pervasive in controversies on human enhancement and is taken for granted by both sides of many debates on the subject, no matter how distant one side happens to be from the other. However, before describing the situation in the case of enhancement, I will discuss the shortcomings of political moralism and political realism and will introduce an alternative, political minimalism. (Rodríguez Alcázar 2017, II2)

This is a discussion of the moral, political, and social considerations for a course of action, in this case human enhancement capabilities, and the rights and duties that arise from these possibilities. What if the domain of ethics is really another forum for dealing with difference, albeit one with agreed foundational rules (based on human rights), bottom-lines, and methodologies? In other words, ethics like politics is not a settled place but a place where settlements are found? The difference between politics and ethics may lie in the fact that the former settles an issue by the art of the possible in social terms, whereas ethics, hopefully, identifies core values and interests and does not just settle on what those who hold power (whether democratically or not?) think is desirable in the society in question and politically expedient, in others words there is no moral bottom line necessarily to a political settlement.

In Including People with Dementia in Research: An Analysis of Australian Ethical and Legal Rules and Recommendations for Reform, Nola M. Ries, Katie A. Thompson, and Michael Lowe, from Australia, undertake a review of the challenges of involving people with impaired cognition, due to dementia, a major evolving global health issue, in research (Ries et al. 2017). It uses the variations of regimes amongst the state and territory jurisdictions in a federal country (Australia) as a case study of the ethical issues at stake and potential reforms that should be considered.

In Measles Vaccination is Best for Children: The Argument for Relying on Herd Immunity Fails, Johan Christiaan Bester from the United States and South Africa argues that measles vaccination is a moral responsibility for parents and guardians of children and that there is only justification for non-vaccination of children who have specific medical contraindications, who must then rely on herd immunity (Bester 2017). This position is based on the medical data that the disease is serious, morbid, and has significant complication rates. This view is contested, mainly in Western countries, by those who see measles merely as an unpleasant exanthematous childhood illness and a necessary part of a child's "natural" immunityacquiring journey. This fundamental difference in world view is a fault-line that is hard to bridge, a collision of views about nature and our power to master it, and understandings of the collateral damage of doing so (see also Koski and Holst 2017 below).

Medical Negligence Determinations, the "Right to Try," and Expanded Access to Innovative Treatments by Denise Meyerson of Australia, contributes an analysis of legislative attempts in the United Kingdom and United States to allow doctors to try innovative treatments without the danger of legal actions for harms resulting from such new interventions (Meyerson 2017). Fear of such actions is seen as impeding medical progress and depriving patients of potentially beneficial treatments, usually in situations where no good alternatives exist.

Access to High Cost Cancer Medicines Through the Lens of an Australian Senate Inquiry-Defining the "Goods" at Stake, by Narcyz Ghinea, Miles Little, and Wendy Lipworth from Australia, analyses the emotive issue of providing expensive new cancer drugs based on the understandable desperation of people with cancer for whom no other therapy is available (Ghinea et al. 2017). The authors urge caution in allowing these very human pressures to circumvent good science and process, including the need to ensure efficacy, safety, and resource distribution priorities in health systems.

Exploring Vaccine Hesitancy Through an ArtistScientist Collaboration Visualizing Vaccine-Critical Parents' Health Beliefs by K. Koski and J. Holst, from Finland and Norway, describes an innovative methodology used to explore the reasons why parents reject immunizations (Koski and Holst 2017). This is an example of a truly novel and creative approach to investigate bioethical issues:

The experimental methodology of this study revolves around the translation of the parents' health belief narratives into arts-based diagrammatic interpretations by the artist-researcher. These diagrams represent the main findings of the qualitative interview data, making the selected health 
beliefs visible and functioning as a vehicle for interdisciplinary conversation about them. (II1 under "Designing the Diagrams")

We are pleased to publish the 2016 AABHL John McPhee (Law) Student Essay Prize winner: DecisionMaking Capacity and Unusual Beliefs, Two Contentious Cases by Brent Hyslop, from New Zealand (Hyslop 2017). This essay, published as submitted from the judging process, gives a commentary on two U.K. legal cases where the seemingly unconventional medical choices of citizens are tested for decision-making capacity in a legal context. Peoples' choices may not make sense to us, but if no one is harmed, and there is not unreasonable demand placed on the health system, we are surely entitled to make what may seem to others to be our own "mistakes."

In A Feminist Critique of Justifications for Sex Selection, Tereza Hendl from Australia makes an argument against parents being able to choose the sex of a baby based on the principle that the exercising of such a parental right (if such a right is accepted) is inherently sexist and may have bad consequences for the child so chosen, and for society in general, by placing a higher value in the choosing of one sex over another (Hendl 2017).

In a review of A 450-Year-Old Turkish Poem on Medical Ethics Halil Tekiner, from Turkey, observes that

... even after 450 years of existence, Vasiyyetname [by the Ottoman physician-poet Nidai of Ankara (1509 to post-1567] retains its ethical and artistic relevance and still serves as a vehicle for the transmission of humanistic ideals far beyond the time and place it was written. (Tekiner 2017, I1 under "Conclusion")

Here is a taste of this wisdom: "See all people as equals / See the humble as heroes" and "Don't boast of reading, mastering science / Or of all your prayers and obeisance / If you don't identify Man as God / All your learning is of no use at all" (quoted in I[3 under "Historical Origins of Vasiyyetname"). A plea for justice and holism from well before we try to reincarnate such values in our own time?

Ilana Maymind of the United States, reviews "Never Die Alone: Death and Birth in Pure Land Buddhism" by Jonathan Watts and Yoshiharu Tomatsu (Maymind 2017). The book is a collection of essays about aspects of the Shin (Pure Land) Buddhist approaches to death and dying. Two quotes from the review show the disarmingly simple but challenging discipline of this spiritual path:

To address the challenge of dying a peaceful death (and hence attaining a desired rebirth), religious professionals, called zenchishiki, were brought in to assist the dying. The practice of chanting became a central means of supporting the dying. The state of mind was then maintained by the whole group, and the dying person did not carry the entire burden of mental concentration on his or her own. As a result of this practice, shonen became an intersubjective experience ... (II3)

A spiritual injunction to treat every moment of one's life as the last one is repeated so often that it loses its urgency and becomes a cliché. (II18)

Finally, below, we publish a piece by one of our Consulting Editors, David Shaw from Basel and Maastricht (Shaw 2017). He explores the issue of organ donation as an extension of a person doing good in the world that they have left based on the Greek philosophical concept of eudaimonia. Whilst written from a base of philosophy and ethics, it also inevitably touches on the existential and perhaps also spiritual dimension of life and its meaning: a last altruistic gift to those who may live on as a result of the donation. Eudaimonia across one's entire life, and karma, a legacy after physical death, ... a similarity across time and culture?

\section{References}

Bester, J.C. 2017. Measles vaccination is best for children: The argument for relying on herd immunity fails. Journal of Bioethical Inquiry 14(3). doi.10.1007/s11673-017-9799-4.

Ghinea, N., M. Little, and W.L. Lipworth. 2017. Access to high cost cancer medicines through the lens of an Australian senate inquiry-Defining the "goods" at stake. Journal of Bioethical Inquiry 14(3). doi.10.1007/s11673-017-9800-2.

Hendl, T. 2017. A feminist critique of justifications for sex selection. Journal of Bioethical Inquiry 14(3). doi.10.1007 /s11673-017-9797-6.

Hyslop, B. 2017. Decision-making capacity and unusual beliefs: Two contentious cases: Australian Association of Bioethics and Health Law John McPhee (law) student essay prize. Journal of Bioethical Inquiry 14(3). doi.10.1007/s11673017-9795-8.

Koski, K., and J. Holst. 2017. Exploring vaccine hesitancy through an artist-scientist collaboration: Visualizing vaccine-critical 
parents' health beliefs. Journal of Bioethical Inquiry 14(3). doi.10.1007/s11673-017-9798-5.

Maymind, I. 2017. Review of Never die alone: Death and birth in pure land Buddhism, by J. Watts and Y. Tomatsu. Journal of Bioethical Inquiry 14(3). doi:10.1007/s11673-017-9788-7.

Meyerson, D. 2017. Medical negligence determinations, the "right to try," and expanded access to innovative treatments. Journal of Bioethical Inquiry 14(3). doi. 10.1007/s11673017-9791-z.

Raposo, V.L. 2017. Are wrongful life actions threatening the value of human life? Journal of Bioethical Inquiry 14(3). doi. 10.1007/s11673-017-9792-y.

Richards, B., and T.M. Pope. 2017. Stretching the boundaries of parental responsibility and new legal guidelines for determination of brain death. Journal of Bioethical Inquiry 14(3). doi.10.1007/s11673-017-9803-z.
Ries, N.M., K.A. Thompson, and M. Lowe. 2017. Including people with dementia in research: An analysis of Australian ethical and legal rules and recommendations for reform. Journal of Bioethical Inquiry 14(3). doi. 10.1007/s11673-017-9794-9.

Rodríguez Alcázar, J. 2017. Political minimalism and social debates: The case of humanenhancement technologies. Journal of Bioethical Inquiry 14(3). doi.10.1007/s11673-017-9790-0.

Šarić, L., I. Prkić, and M. Jukić. 2017. Futile treatment-A review. Journal of Bioethical Inquiry 14(3). doi. 10.1007/s11673017-9793-x.

Shaw, D. 2017. A virtuous death: Organ donation and eudemonia. Journal of Bioethical Inquiry 14(3). doi.10.1007/s11673017-9802-0.

Tekiner, H. 2017. A 450-year-old Turkish poem on medical ethics. Journal of Bioethical Inquiry 14(3). doi:10.1007/s11673017-9789-6. 